\title{
River network evolution and fluvial process responses to human activity in a hyper-arid environment - Case of the Tarim River in Northwest China
}

\author{
Guo-An Yu ${ }^{\mathrm{a}, \mathrm{b}, *}$, Markus Disse ${ }^{\mathrm{b}}$, He Qing Huang ${ }^{\mathrm{a}}$, Yang $\mathrm{Yu}^{\mathrm{b}}$, Zhiwei $\mathrm{Li}^{\mathrm{c}}$

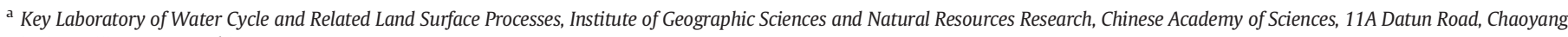 \\ District, Beijing 100101, China \\ b Technical University of Munich (TUM), Arcisstrasse 21, Munich 80333, Germany \\ c School of Hydraulic Engineering, Changsha University of Science E Technology, Changsha, 410114, China
}

\section{A R T I C L E I N F O}

\section{Article history:}

Received 19 June 2015

Received in revised form 21 June 2016

Accepted 27 June 2016

Available online 12 July 2016

Keywords:

Channel network evolution

Fluvial processes

Human impacts

Dryland river

Tarim River

\begin{abstract}
A B S T R A C T
The Tarim River, the longest dryland river in an extremely arid region of China, has undergone ever-increasing human impacts over recent centuries (particularly since the late 1950s during which time large-scale land reclamation in the basin has taken place). Historical literature/maps, gauged hydrological data and satellite images were analyzed to examine how the river network evolution in the basin and the fluvial morphology of the main stem of the Tarim River have responded to human influences. The results demonstrate that human activity (inhabitation, land reclamation and water resources development) in the basin have had significant impacts on the Tarim River, causing major changes in runoff and sediment transport, river network composition and river morphology (especially planform patterns). Gauged hydrological data from the past five decades presented an obvious reduction in runoff and sediment load in the Tarim River, even though the runoff from source tributaries exhibited a gentle increase. The annual occurrence of low flow events showed a significant increase, and the occurrence of moderate-high flow events followed a gentle decrease. The river network system has disintegrated from a historically '(quasi-) centripetal' system with nine tributaries into several isolated river systems, which have mainly developed since the 20th century. Currently, only four tributaries flow into the main stem river, which is dominated by braided channel patterns in the upper reaches and meandering (typically with distorted bends) patterns in the middle reaches. The braided reach was in aggradation and in high lateral mobility. The mean width and braiding intensity of the braided reach followed a gentle decrease mainly due to the reclamation of river flood plains to farmlands and embankments. The sinuosity index of the current Tarim River channel is distinctively lower than the indexes of the old channels that were abandoned decades or centuries ago, even though the sinuosity index of the meandering channel followed a gentle increase in recent decades due to the increased occurrence of low flow events. Human activity has changed the natural fluvial processes and morphology of the Tarim River and has reduced the diversity of the river network system.
\end{abstract}

(c) 2016 Elsevier B.V. All rights reserved.

\section{Introduction}

The arid zones on Earth cover $30 \%$ or more of the global land surface and support an ever-growing human population (Thomas, 2011). Rivers in these zones often play a central role in landscape change and exert a strong influence on the human use of these marginal environments (Tooth and Nanson, 2011). Therefore, the processes, forms and changes of these rivers are increasingly a focus of scientific and applied research. Among this research, many have investigated the hydrological regimes, sediment dynamics and fluvial processes of these rivers (e.g.,

\footnotetext{
* Corresponding author at: Key Laboratory of Water Cycle and Related Land Surface Processes, Institute of Geographic Sciences and Natural Resources Research, Chinese Academy of Sciences, 11A Datun Road, Chaoyang District, Beijing 100101, China.

E-mail address: yuga@igsnrr.ac.cn (G.-A. Yu).
}

Leopold and Miller, 1956; Leopold et al., 1964; Graf, 1988; Laronne and Reid, 1993; Thornes, 1994; Knighton and Nanson, 1994, 1997, 2001; Tooth and Nanson, 1999, 2004; Tooth, 2000b; Alexandrov et al., 2003; Achite and Ouillon, 2007; Reid and Frostick, 2011; Powell et al., 2012).

Human activity has had a substantial influence on fluvial processes and even on the modification of river networks; numerous studies have investigated human impacts, emphasizing rivers in temperate and humid regions (e.g., Brooks and Brierley, 1997; Surian and Rinaldi, 2003; Liébault et al., 2005; Gregory, 2006; Wohl, 2006; Hoffman et al., 2010; Rhoads et al., 2015). With the accelerated expansion of human activities from temperate and humid environments into arid environments, many dryland rivers have already been strongly influenced by, or are under significant threat from, various human interventions such as land reclamation and flow regulation, which often have more 
significant potential to disturb hydrological (e.g., Jacobson et al., 1995; Schick, 1995; Tooth, 2000a; Mansur and Nurkamil, 2010; McDonald et al., 2013) and fluvial processes (e.g., Graf, 1978, 1979; Ortega et al., 2014). Related research has mainly been carried out in recent decades, for example, the changing channel patterns of the Gila River in Arizona, in the southwestern United States of America, resulting from flow regulation and the introduction of Tamarix, an exotic plant with more suitability than local vegetation (Graf, 1978, 1979, 1988); the flow regime and hydrologic change of the Murray and the Barwon-Darling Rivers (Maheshwari et al., 1995; Thoms and Sheldon, 2000); the adjusted channel morphology of ephemeral streams due to urbanization in southwest America (Chin and Gregory, 2001; Coleman et al., 2005); and changes in the dynamics and morphology of ephemeral rivers in Mediterranean regions (Hawley and Bledsoe, 2011, 2013). In general, most fluvial morphology-related studies were conducted on ephemeral rivers at relatively small spatial scales (dozens to hundreds of square kilometers) and basically belong to endogenic system in hydrologic feature. However, minimal attention has been paid to the evolution of river networks and fluvial processes of allogenic rivers in arid environments.

The Tarim River, the largest inland river in China, is a typical allogenic and perennial river flowing in a hyper-arid environment and has been massively modified in recent decades. Despite several studies that have examined human impacts on the environment, ecology and variation of the hydrologic regime in the basin (e.g., Han, 1980; Feng et al., 2005; Chen et al., 2010), investigation into the response of fluvial processes is weak and needs to be strengthened because this knowledge is important for understanding the changes in large dryland river systems, possibly shedding light on their potential evolution in the future and enhancing sustainable management strategies for river systems in arid environments.

This paper outlines the human activities that have occurred in the Tarim River Basin in recent centuries (especially in the past five decades) and traces the evolution of the river network system back in history, going on to examine in detail how the fluvial morphology of the Tarim River has changed in recent decades in response to changes in hydrologic and sediment dynamics from ever-increasing human impacts.

\section{Research area and methods}

\subsection{Research area}

Located in the northern Qinghai-Tibetan Plateau, the Tarim Basin is the largest inland river basin in China, encompassing a total basin area of $1.02 \times 10^{6} \mathrm{~km}^{2}\left(35^{\circ} \mathrm{N}-43^{\circ} \mathrm{N}, 74^{\circ} \mathrm{E}-90^{\circ} \mathrm{E}\right.$ ) (Fan et al., 2006) (Fig. 1). The basin, also called the Southern Xinjiang (or Nanjiang in Chinese Pinyin) Basin in Chinese geographical references, is surrounded by the high mountains of the Tianshan, Eastern Pamir, Kunlun, Karakorum and Aerhchin ranges, which results in orographic precipitation patterns. The current main stem of the Tarim River has a channel length of approximately $1321 \mathrm{~km}$, starting from XJK (Xiaojiake, the confluence site of the Aksu, Yarkand and Hotan Rivers), basically flowing from the west to the east, then to the southeast, finally emptying into Taitema Lake. The natural ecosystem and human activities in this hyper-arid basin rely heavily on water resources, directly or indirectly, from the Tarim River.

The climate of the continental basin is extremely dry with very large temperature fluctuations; the highest and lowest recorded temperatures were $43.6^{\circ} \mathrm{C}$ and $-27.5^{\circ} \mathrm{C}$, respectively. Although annual precipitation in the mountainous headwater regions can reach approximately $200-500 \mathrm{~mm}$, it is only $50-80 \mathrm{~mm}$ in the main stem area (and just $10 \mathrm{~mm}$ in the central desert area) (Chen et al., 2009), whereas the annual potential evaporation amounts to $2100-3000 \mathrm{~mm}$ or more (Feng and Cheng, 1998). The Tarim River can be regarded as an allogenic (exotic) river because its surface runoff is basically fed from snowmelt and

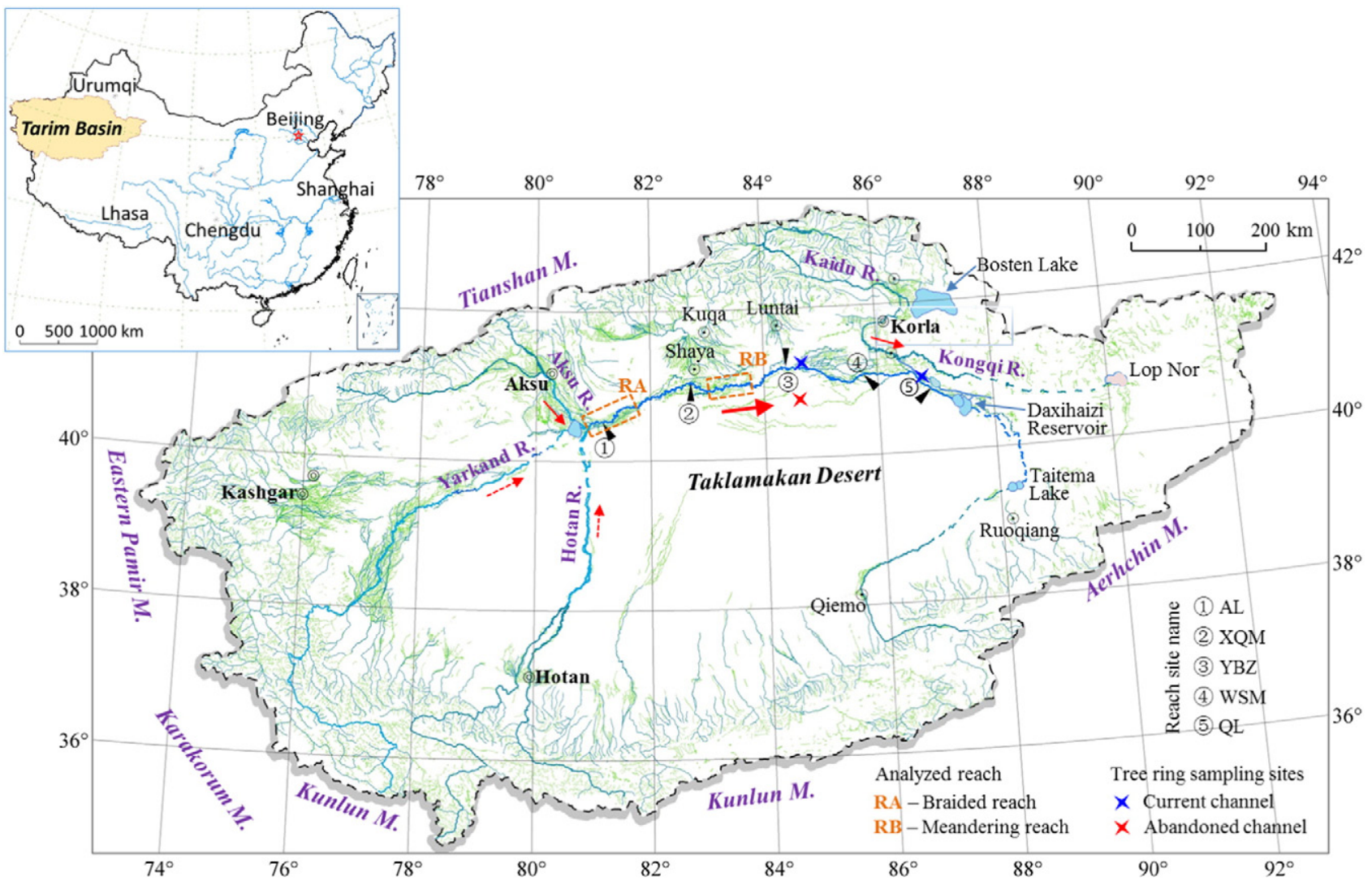

Fig. 1. Location of the Tarim River Basin and its current river network system. 
Table 1

Features of flow and sediment at representative gauge stations in the main stem of the Tarim River.

\begin{tabular}{|c|c|c|c|c|c|c|c|c|c|c|c|}
\hline \multirow[b]{3}{*}{ Gauge station } & \multicolumn{6}{|l|}{ Flow $^{\mathrm{a}}$} & \multicolumn{5}{|c|}{ Suspended sediment ${ }^{\mathrm{b}}$} \\
\hline & \multicolumn{3}{|l|}{$\mathrm{Q}\left(\mathrm{m}^{3} / \mathrm{s}\right)$} & \multirow[b]{2}{*}{$\mathrm{CV}$} & \multirow[b]{2}{*}{$\mathrm{CS}$} & \multirow[b]{2}{*}{$\mathrm{P}_{\mathrm{Ql}}(\%)$} & \multicolumn{2}{|l|}{$\mathrm{SSC}\left(\mathrm{kg} / \mathrm{m}^{3}\right)$} & \multirow[b]{2}{*}{$\mathrm{CV}$} & \multirow[b]{2}{*}{ CS } & \multirow[b]{2}{*}{$\mathrm{P}_{\mathrm{Sl}}(\%)$} \\
\hline & Range & $\mathrm{Q}_{\mathrm{m}}$ & $\mathrm{Q}_{\mathrm{m} \_2}$ & & & & Range & $\mathrm{SSC}_{\mathrm{m}}$ & & & \\
\hline $\mathrm{AL}$ & $0.42-2130$ & 148.7 & 503 & 1.41 & 2.9 & 43.6 & $0.017-21.6$ & 4.9 & 1.39 & 2.32 & 0.64 \\
\hline $\mathrm{XQM}$ & $0.01-1680$ & 118.6 & 422.3 & 1.6 & 2.6 & 46 & $0-12$ & 5.0 & 1.25 & 2.01 & 0.36 \\
\hline QL & $0-150$ & 24.8 & 63.6 & 1.68 & 2 & 49.7 & $0-0.96$ & 0.2 & 0.93 & 1.73 & 2.47 \\
\hline
\end{tabular}

Range: Minimum daily mean value-Maximum daily mean value;

$\mathrm{Q}_{\mathrm{m}}$ : Annual mean discharge over the study years;

$\mathrm{CV}$ : Coefficient of variation of the analyzed samples;

CS: Skewness of the analyzed samples;

SSC: Daily mean value of the suspended sediment concentrations;

$\mathrm{SSC}_{\mathrm{m}}$ : Mean annual value of suspended sediment concentrations over the study years;

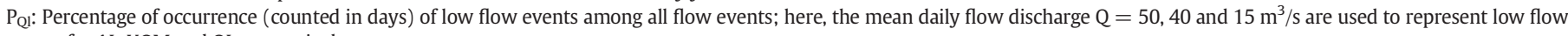
events for AL, XQM and QL, respectively;

$\mathrm{P}_{\mathrm{Sl}}$ : Percentage of sediment load transported by low flow events of the annual sediment load.

a Flow data series: 1960-2011 (AL); 1957-2011 (XQM); 1957-1960 and 2006-2008 (QL).

b Suspended sediment data series: 1960-1966, 1978-1989 and 2001-2011 (AL); 1962-1971 (XQM); 1959 (QL).

glacier-melt in the Tianshan and Kunlun Mountains, rather than from local precipitation.

Hydrologic gauging stations were established in the late 1950s for hydrometric monitoring at AL (Alar), XQM (Xinquman) and QL (Qiala), corresponding to reach sites 1, 2 and 5, respectively, in Fig. 1. The AL gauging station (site 1 in Fig. 1) is the first station on the main stem of the Tarim River after the three source tributaries (i.e., the Aksu, Yarkand and Hotan Rivers) join near XJK (approximately $48 \mathrm{~km}$ upstream of AL); therefore, the hydrologic regime at AL represents the incoming flow and sediment conditions of the main stem of the Tarim River. The basic features of flow and sediment at the AL, XQM and QL stations in the main stem Tarim River are shown in Table 1. The large ratios of maximum and minimum values of flow discharge and sediment concentration indicate that the flow discharge and sediment transport are highly varied. The large and positive skewness (CS) values indicate the asymmetric distribution and the tail on the right side is longer and fatter than on the left side; in other words, events with low flow discharge and corresponding low suspended sediment concentrations have a high percentage among the total flow events, although these events make a small contribution to the annual runoff and sediment load. The mean annual values of runoff and sediment load to the main stem of the Tarim River are approximately $4.7 \times 10^{9} \mathrm{~m}^{3}$ and $22 \times 10^{6}$ tons, respectively, based on monitored flow data at AL from 1960 to 2011 . The sediment load is highly concentrated (the load in the flood season amounts to approximately $95 \%$ of the annual load). The mean annual runoff and sediment load decrease spatially from upstream to downstream due to transmission losses and water diversion, and very low runoff and sediment load (just $0.8 \times 10^{9} \mathrm{~m}^{3}$ and $0.2 \times 10^{6}$ tons) moves farther downstream of QL (Fig. 2 a). The runoff into the Tarim River (evaluated based on the runoff at AL, the most upstream gauge section in the main stem of the Tarim River) followed a decreasing trend, though incoming water resources from the headwater regions exhibited an increasing trend over the last several decades (Fig. 2 b).

Our study focuses mainly on the evolution of the river network across the entire Tarim Basin and on the hydrodynamic and fluvial morphology of the upper and mid-reaches of the main stem of the Tarim River, i.e., the reach from XJK (the site of the three-tributary-confluence) to QL (Fig. 1, upstream reach from site 1 to site 5) with a channel length of approximately $900 \mathrm{~km}$. Because very low flow discharge occurs downstream from QL ( site 5), the river flow is no longer the main influence on channel morphology in these reaches; therefore, these reaches were not considered in this analysis.

\subsection{Data and research methods}

Human activities, channel networks and planform changes in the river in recent centuries (especially in recent decades) were analyzed based on historical literature/maps, gauged hydrological data and satellite images.

\subsubsection{Literature/map/data access}

Several important historical literature sources and maps (Ban, ca. 80*; Li, ca. 515-524§; Xuanzang, ca. $646^{\dagger}$; Fu et al., $1782^{\ddagger}$; Hedin, 1898 , 1904) were referenced to understand social development (inhabitants, farmland area) and river networks in the basin during different historical periods. These literature sources were all valuable contributions to Chinese history and (physical \& social) geography, and the body of information related to the Tarim Basin is generally considered reliable since it has been analyzed and referred to in other studies (e.g., Fan, 1979; Wang, 1987; Fan et al., 2006, 2009; Hu et al., 2005).

The daily mean flow discharge $(\mathrm{Q})$ and daily mean suspended sediment concentrations (SSC) were collected in a time series from the Annual Hydrological Report of China (Ministry of Water Resources of China, MWRC) to analyze the hydraulic flow features. In addition, the channel bed profiles of cross sections at AL and XQM surveyed by the Tarim River Conservation Commission one to several times per year (also on hiatus in some years) over the past three decades were acquired for the analysis of bed elevation variations.

Landsat satellite images from past decades (generally from the late 1970s) were obtained to examine the planform features (mean channel width, braiding intensity, sinuosity index) and river patterns. To be consistent in the analysis, only images from the non-flood season were used.

\subsubsection{Methods}

ENVI 5.2 and ArcGIS 10.1 were used to process the satellite images and extract the channel centerline \& channel boundary. The extracted channel centerline and channel boundary were then used to compare lateral channel mobility and to measure the channel length, plan area, mean channel width, braiding intensity and sinuosity index. For the measurement of channel length, the longitudinal length of the channel centerline was measured. If the channel was braided, the largest branch was used. The mean channel width was calculated by dividing the

\footnotetext{
* Ban Gu. Book of Han (History of Western Han Dynasty), vol. 96, Traditions of the Western Regions, ca. 80 CE;

$\S$ Li Daoyuan. Records of Rivers in China, ca. 515-524 CE. This was a famous Chinese geographical book specializing in river geography and containing descriptions of rivers in the Western regions in China;

${ }^{\dagger}$ Xuanzang. The Great Tang Dynasty Record of the Western Regions, ca. 646 CE;

${ }^{\ddagger}$ Fu Heng, Chu Tingzhang, Ying Lian, et al. The Imperial Atlas of western region (Xinjiang) in China, 1782. The atlas was based on a geographical survey in Xinjiang in the mid-1750s, which was commissioned by Emperor Qianlong (1711-1799). It illustrates the Tarim River network in the mid Qing Dynasty.
} 
(a)

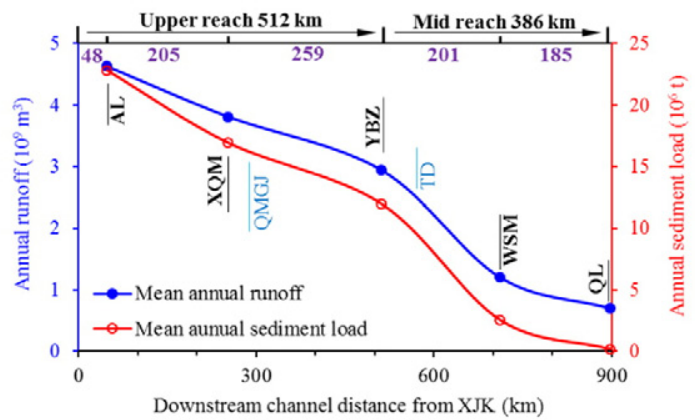

(b)

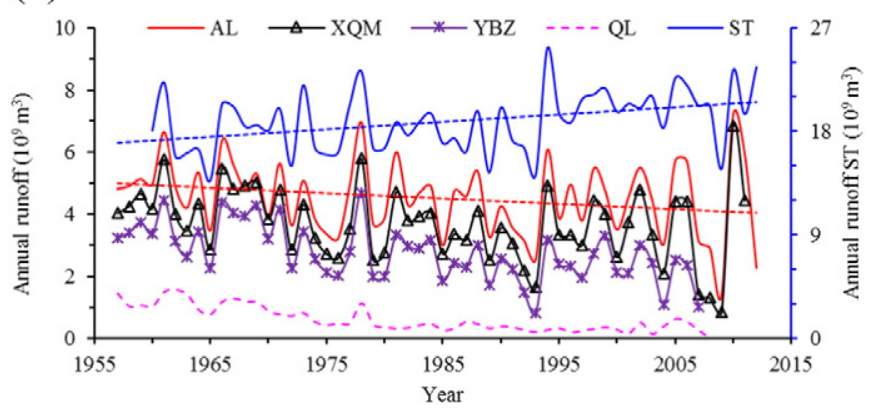

Fig. 2. (a) Spatial distribution of the mean annual runoff and sediment load in recent decades (1956-1999) along the main stem of the Tarim River (XJK is the confluence of the Aksu, Yarkand and Hotan Rivers); (b) temporal variations of runoff from source tributaries (ST) and at representative gauge stations. Note that the plot of runoff ST corresponds to the secondary vertical axis.

channel plan area by the length of the centerline of the corresponding channel. The sinuosity index was calculated as the ratio of the channel centerline length to the sum of the channel-belt axis lengths. Since the sinuosity index of single meanders in the main stem of the Tarim River differed greatly, a mean value of multi-meanders along a certain distance of river reach was used to represent an average degree of sinuosity. Braiding intensity was measured referring to the 'Channel Count' method (c.f., Howard et al., 1970; Egozi and Ashmore, 2008).

Because the cross-sectional surveys in the Tarim River were both temporally and spatially minimal, it was hard to effectively quantify the aggradation or incision of a certain reach. Furthermore, since the reach near the two surveyed sections was quite unstable (strongly braided and wandering), it was also not easy (nor effective) to judge whether the channel was aggraded or incised by just comparing the bed elevation at a certain location (e.g., the thalweg of the channel). Therefore, the mean bed elevation, $E_{m}$, was used to evaluate the variation of bed elevations. $E_{m}$ is defined here as $E_{m}=A / W$, where $A$ is the enclosed area of surveyed cross-sectional profiles above a fixed reference elevation, and $\mathrm{W}$ is the width of each surveyed channel cross-section profile.

Field investigations were carried out along the main stem of the Tarim River to examine the fluvial morphology of the river channel and to confirm the results from satellite images, including the cross-sectional profile, geometric features, planform patterns and meander development. At representative sites in the current (AL, XQM, YBZ, WSM and QL) and old channels (near YBZ), aeolian zone sediment deposits were sampled. The size distributions of sediment samples were obtained with a laser scattering particle analyzer (MasterSizer 2000).

Representative current and old (abandoned) meandering channels in the Tarim River were also chosen to compare the sinuosity index. The current meandering channels are mainly distributed in the middle reaches of the main stem of the Tarim River (from downstream QMGJ to $\mathrm{QL}$ ), whereas the old (abandoned) meandering channel spread across both the upper and middle reaches of the Tarim River. To differentiate the (relative) age of the current and old (abandoned) channels that were analyzed in this research, tree ring samples were taken from Populos trees near those river channels for analysis. Because the natural Tugai forest in the upper reaches (AL to XQM) was mostly cleared during recent decades, samples were taken near YBZ and QL in the middle reaches, where both the current and old channels distribute and the natural Tugai forest still survives near the old channels (Fig. 1).

\section{Human activity in the Tarim Basin}

One of the important indices representing human activity on the Tarim River is the human population in this basin. The history of human inhabitation can be traced back approximately 3800 years ago, to the ancient town of Loulan (Kroran), but human impacts before the Han Dynasty (206 BCE-220 CE) were negligible, since the population and intensity of human activities at that time were low. Records from the book 'The Great Tang Dynasty Record of the West Regions' (by Xuanzang), which was published in ca. 646 CE, estimated that the population in the Tarim Basin was only approximately 0.23 million in the Western Han Dynasty (the earlier period of the Han Dynasty) (Fan et al., 2009). The population slowly increased to approximately 1.78 million in the late Qing Dynasty (the last imperial dynasty in China, which existed from 1644 to 1912). Therefore, the population increased relatively sluggishly before the 20th century. Subsequently, in the 20th century, especially since the 1950s, it increased much faster when largescale land reclamation began in the basin (Table 2).

Human activity accompanied by an increased population had a substantial impact (or pressure) on the fragile local environment and ecology (e.g., Feng et al., 2005; Mansur and Lutpulla, 2011). Among the various human activities, land reclamation (deforestation, reclamation) and exploitation of water resources (water regulation and storage, water diversion) had a tremendous impact on the river network composition and

Table 2

Population and farmland area in the Tarim Basin (southern Xinjiang) throughout history.

\begin{tabular}{|c|c|c|c|c|}
\hline \multirow[b]{2}{*}{ Year } & \multirow[b]{2}{*}{ Population $\left(10^{6}\right)$} & \multirow[b]{2}{*}{ Farmland area ( $10^{6}$ ha $)$} & \multicolumn{2}{|c|}{ Annual mean rate of increase (\%) } \\
\hline & & & Population & Farmland area \\
\hline Western Han Dynasty* & $0.23^{\mathrm{a}, \mathrm{b}, \mathrm{c}}$ & $0.033^{c}$ & & \\
\hline Early Qing Dynasty ${ }^{* *}$ & $1.5^{\mathrm{d}}$ & & 0.11 & \\
\hline Late Qing in 1911 & $1.78^{\mathrm{d}}$ & $0.6^{\mathrm{c}}$ & 0.06 & 0.14 \\
\hline 1949 & $3.03^{c}$ & $0.71^{\mathrm{d}}$ & 1.37 & 0.44 \\
\hline 2000 & $8.73^{\mathrm{e}}$ & & 2.14 & \\
\hline 2010 & $10.17^{\mathrm{e}}$ & $1.69^{d}$ & 1.54 & 1.43 \\
\hline
\end{tabular}

*Western Han Dynasty (206 BCE-9 CE); ** Qing Dynasty (1644-1912).

a Ban, ca. 80;

b Xuanzang, 646 :

c Fan, 1979;

d Mansur and Lutpulla, 2011;

e 2010 Xinjiang Population census data, http://www.stats.gov.cn/tjsj/tjgb/rkpcgb/dfrkpcgb/201202/t20120228_30407.html 


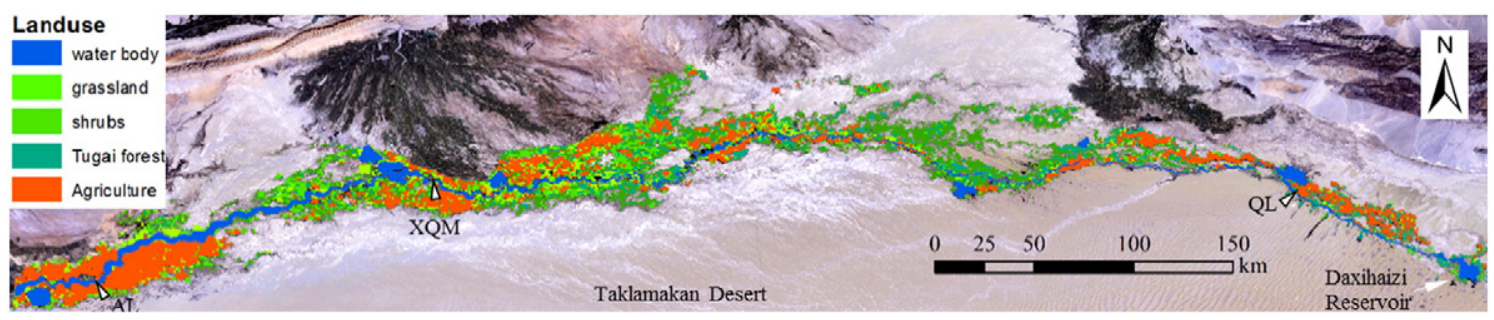

Fig. 3. Land use map showing current vegetation and farmland distribution along the Tarim River (Source: Modis data, 2012).
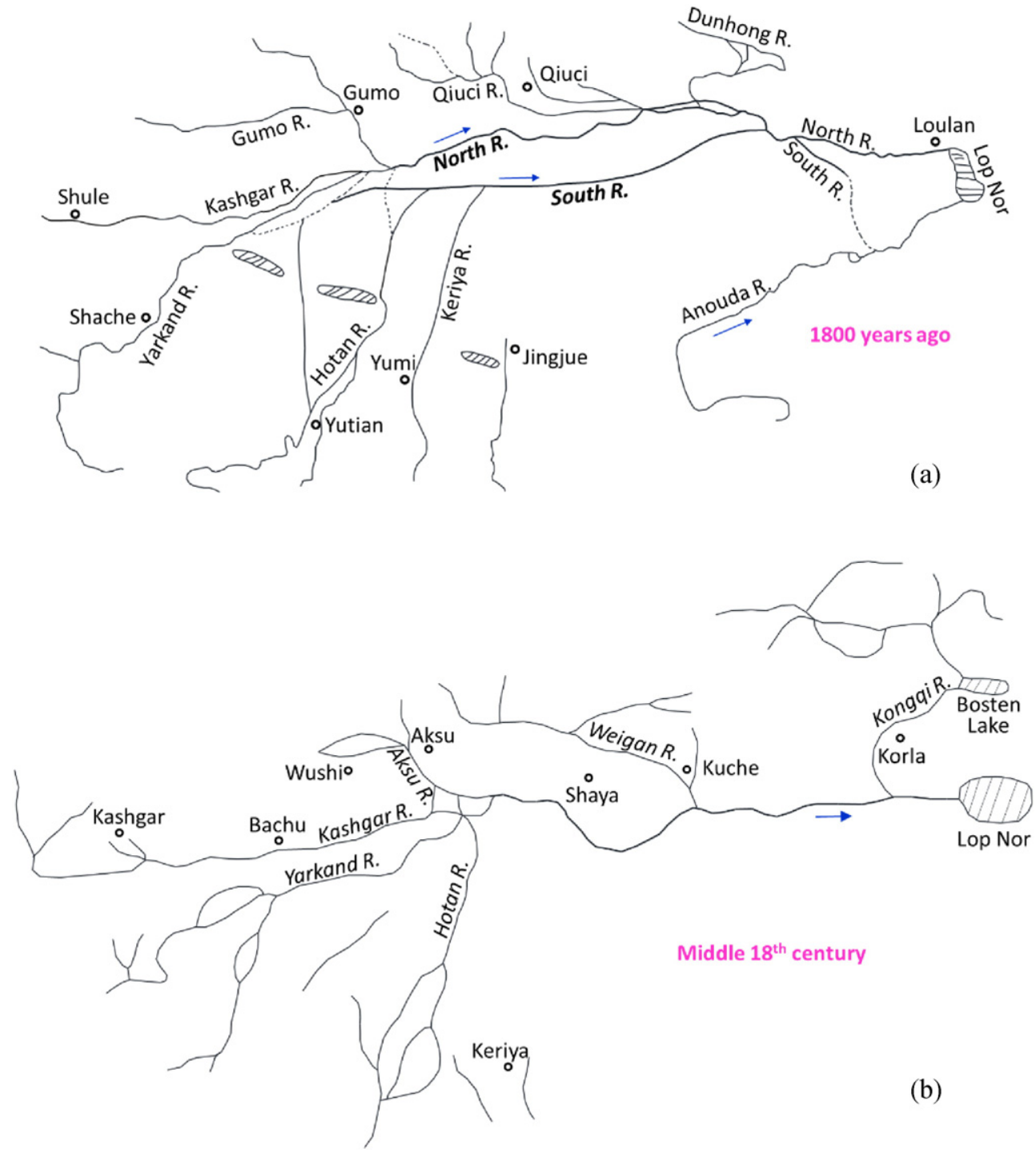

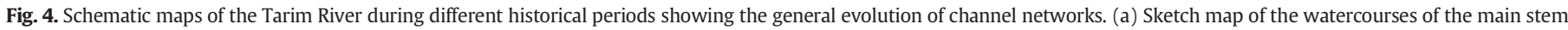

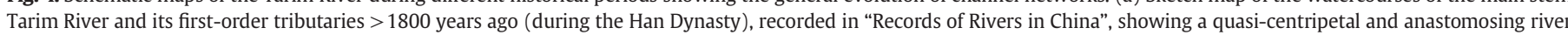

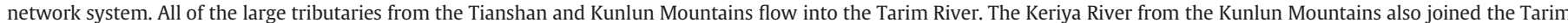

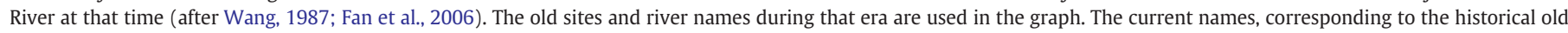

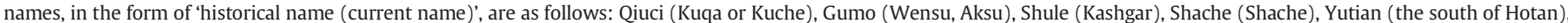

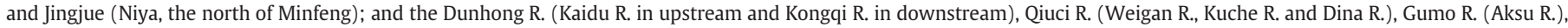

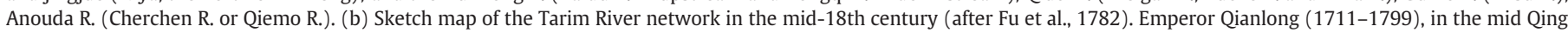

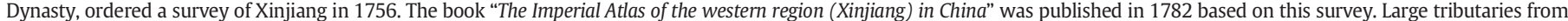

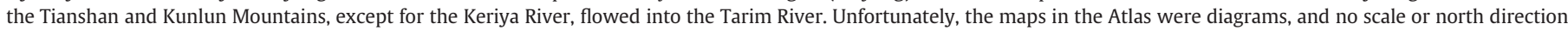

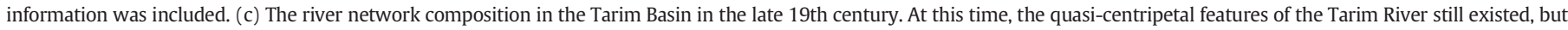

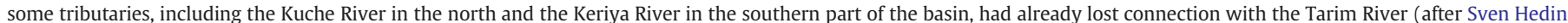

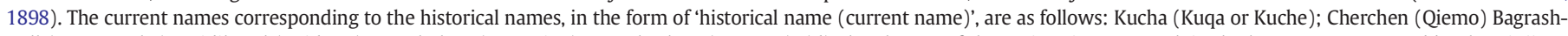

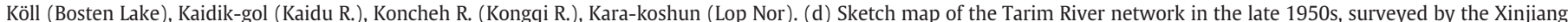

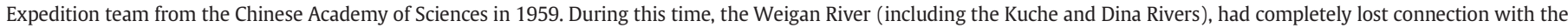

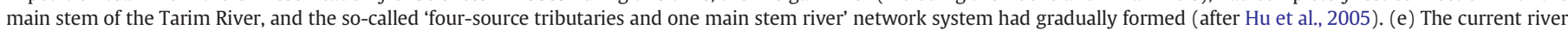
system with only four tributaries linking to the main stem river. 

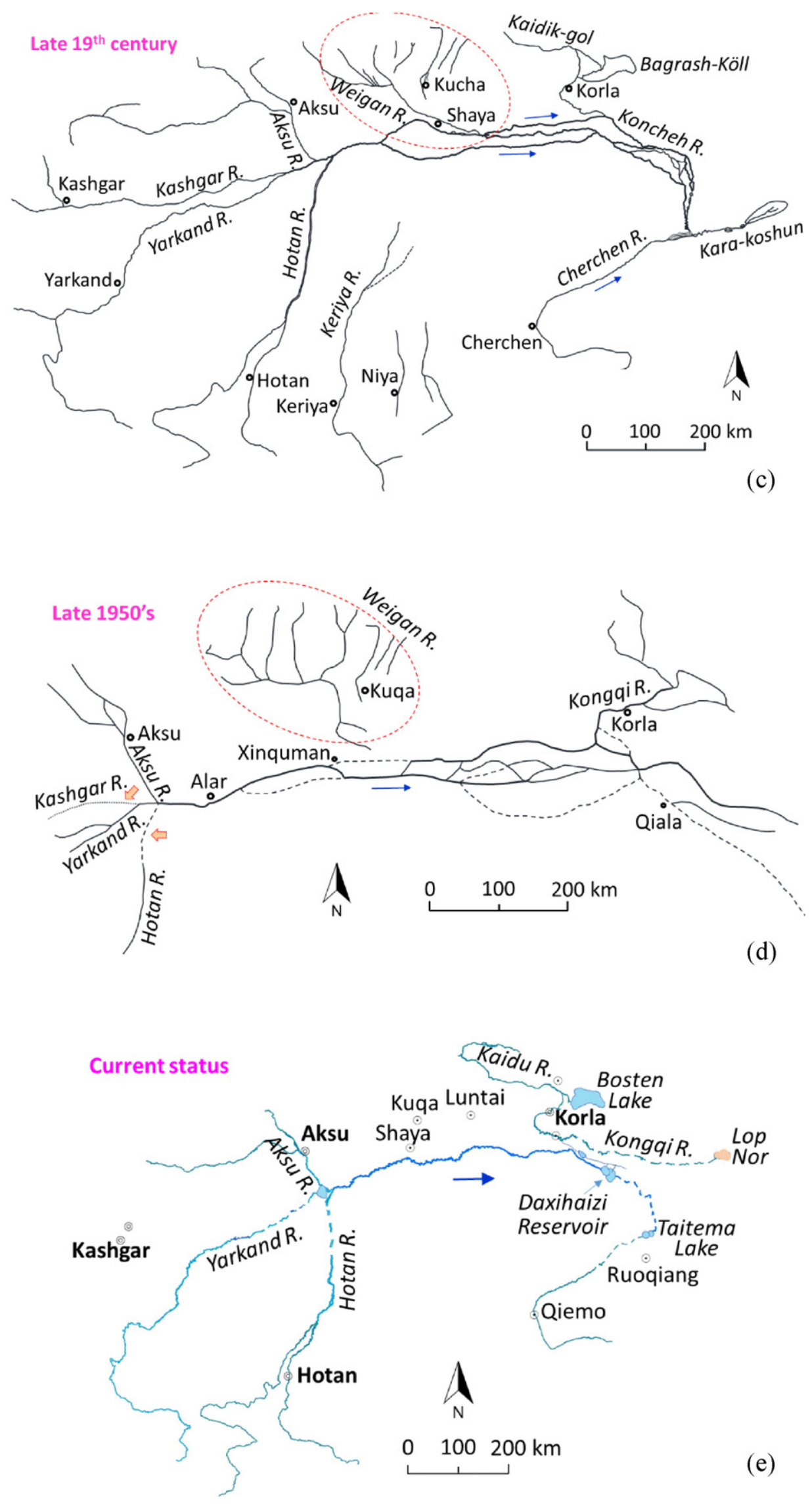

Fig. 4 (continued). 

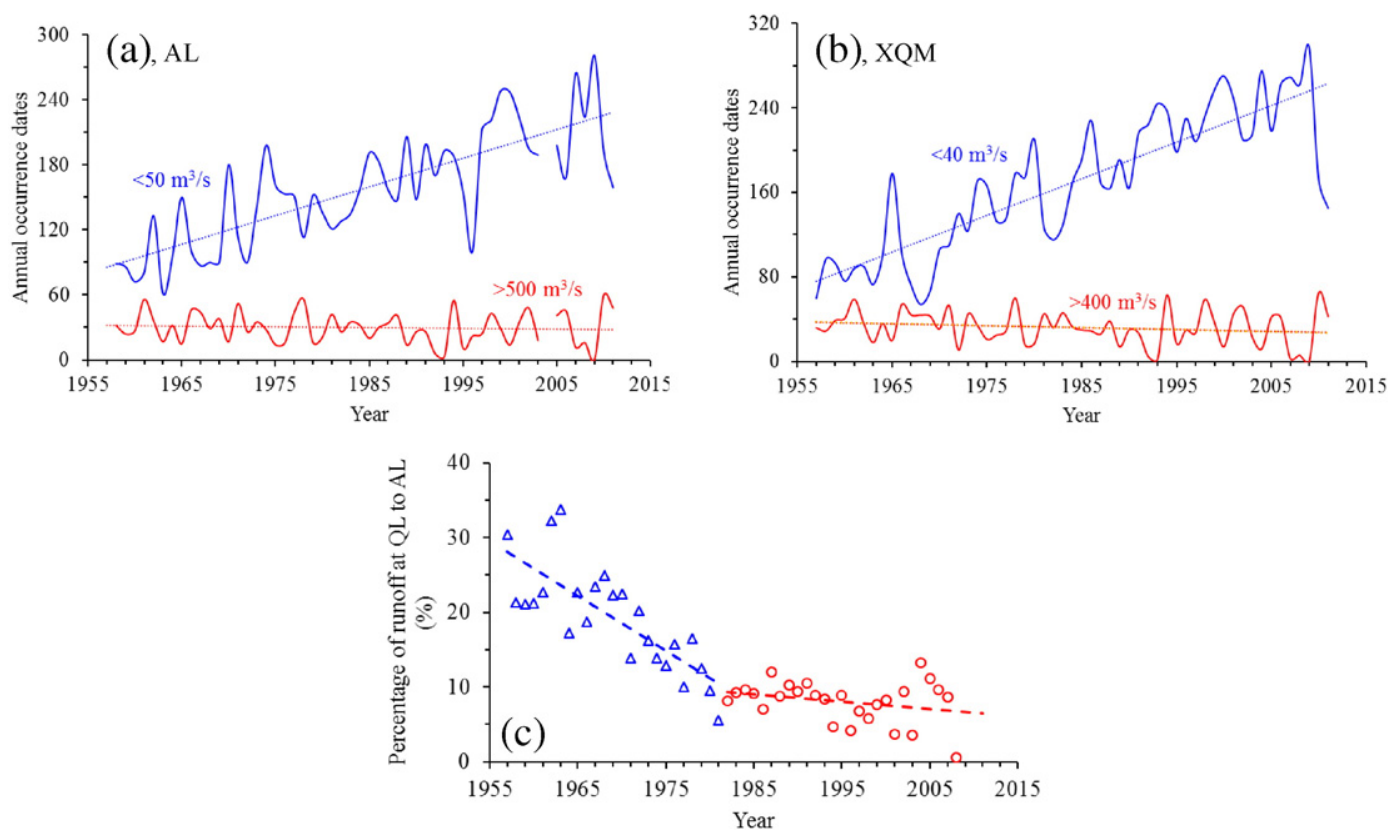

Fig. 5. Variations of annual occurrence of low and moderate-high flow events at $\mathrm{AL}$ (a) and XQM (b); and (c) variation in the percentage of runoff at QL to AL.

channel morphology, since those activities essentially altered the hydrologic, sediment and vegetation conditions across the entire basin.

Over the last century, the farmland area in the Tarim Basin has increased dramatically, compared to the area during the Qing (1644-1912) and earlier dynasties (Table 2). The farmland area during the Han Dynasty (206 BCE-220 CE) was roughly estimated at just 0.033 million ha. It gradually increased to approximately 0.60 million ha during the late Qing Dynasty (Fan, 1979), to 0.71 million ha in 1949 , and then drastically increased to 1.69 million ha in 2010 (Mansur and Lutpulla, 2011).

Parallel to the increase in farmland area, water resource development steadily increased. Statistics indicate that by $1998,>76$ reservoirs had been built on the main stem and large tributaries (such as the Aksu, Yarkand and Hotan) along the Tarim River, with a total storage capacity of $2.55 \times 10^{9} \mathrm{~m}^{3}$; among them, 8 diversion reservoirs were built along the main stem of the Tarim River, achieving a total capacity of $0.59 \times 10^{9} \mathrm{~m}^{3}$. In addition to reservoirs, $>286$ water intake projects were built along the main stem and large tributaries, with a water diversion capacity up to $765 \mathrm{~m}^{3} / \mathrm{s}$. The irrigation area in the upstream Tarim River increased from 0.348 million ha in 1950 to 1.257 million ha in 2000 (Hu et al., 2005). In addition to water consumption in the upstream reaches of the basin, water was also diverted from the main stem of the Tarim River. The annual water diversion volume monitored at four representative reaches (i.e., $\mathrm{AL}, \mathrm{XQM}, \mathrm{YBZ}$ and $\mathrm{QL}$ ) was approximately 0.83 billion $\mathrm{m}^{3}$ in recent years. To stabilize the river channel and control high flows during the main flood season, dykes were built from the middle to lower reaches of the main stem channel, which effectively constrained the natural development of channel lateral mobility.

Natural vegetation in the Tarim Basin declined as a result of landreclamation-induced clearance, water shortage, and the difficulties of regenerating young forests since the chance of flooding decreased. The area of Tugai forest (dominated by Populus euphratica), a typical and dominant vegetation in this arid basin, sharply declined from 0.53 million ha in 1958 to approximately 0.28 million ha in 1979 ( $\mathrm{Lu}$ et al., 1980) and 0.23 million ha in 1989. An investigation in 2009 indicated that the area of the Tugai forest was $<0.2$ million ha (Cheng et al., 2012). The reduced area previously supporting natural vegetation has now predominantly changed to agricultural land, and some has degraded to desert lands (Fig. 3).

\section{River network and channel morphology responses}

\subsection{River network evolution throughout history}

It is difficult, if not impossible, to trace the drainage network evolution of a river across history, since it requires wide and reliable background information such as the geomorphology, geology, sedimentology, paleoclimate, and climate change. Fortunately, related information from historical literature and surveyed maps of the Tarim River Basin supplied us with valuable hints and evidence for this analysis.

We briefly compared the Tarim River networks using schematic maps (graphs) from various representative historical periods (Fig. 4), i.e., • the Han Dynasty ( $>1800$ years ago, quasi-natural status with trivial human impacts), • the mid-18th century during the Qing Dynasty (human impacts still insubstantial), $\bullet$ the end of the 19th century (before rapid population increase in the basin, without large-scale human intervention), $\bullet$ the mid-20th century (after the founding of P.R. China, human impacts on this river becoming ever greater, with the onset of large-scale human intervention), $\bullet$ and the current river system (with large-scale human intervention). This comparison mainly stressed the general composition (and complexity) of the whole river system and the channel pattern changes in the evolution of the river networks, rather than paying much attention to the changes in specific channel routes (river paths), since the Tarim River is very unstable and frequently changes its routes through avulsion or cutoffs. Nevertheless, this

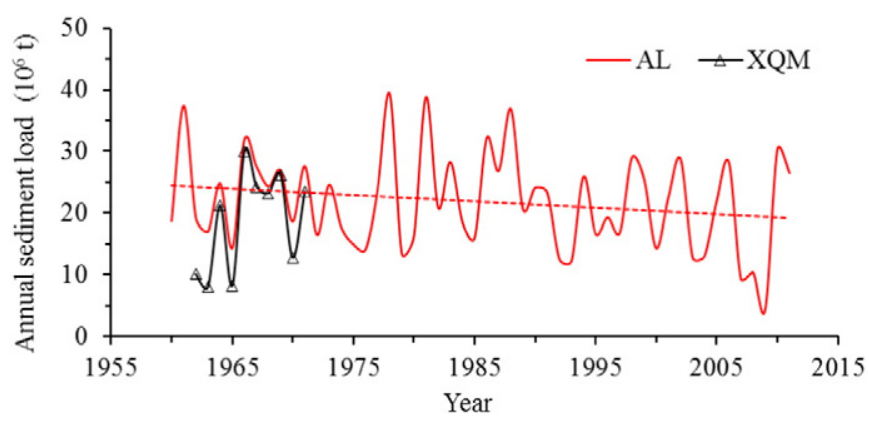

Fig. 6. Variations of sediment load at AL and XQM: fluctuating but decreasing in general. 

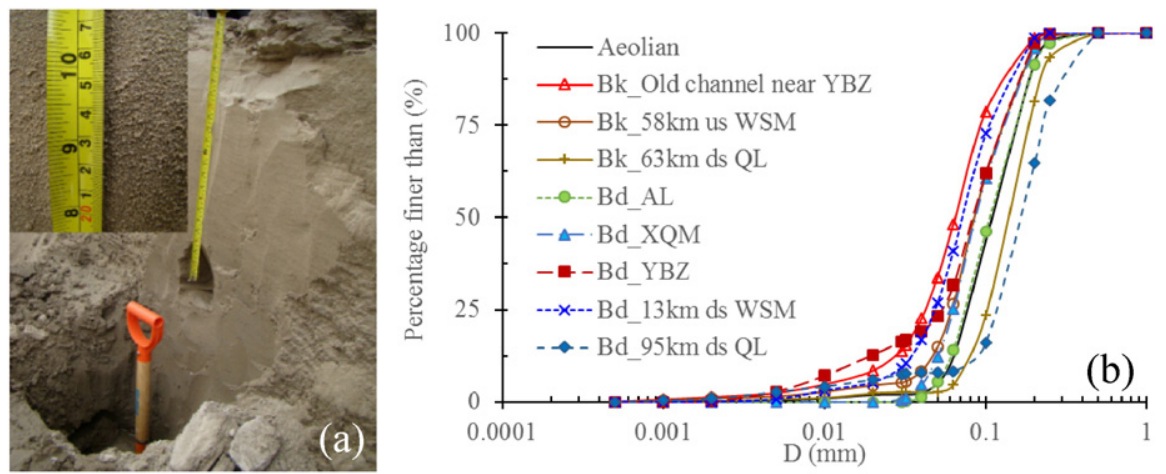

Bk - bank; Bd -bed; us - upstream; ds - downstream

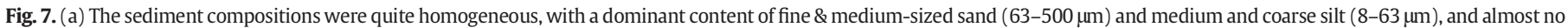

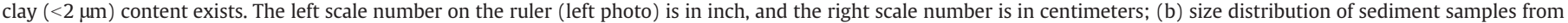
representative reaches of the current channel, old channels and nearby desert.

comparison helped to identify the evolutionary processes of the river network system.

The most significant aspect arising from the comparison was that the tributaries gradually lost their links with the main stem of the Tarim River, primarily in the 20th century, especially since the 1950s after large-scale reclamation and agricultural development in the basin (Fig. 4 a, b, c, d, e).

The Keriya River flows from the Kunlun Mountains in the south and no longer joins the Tarim River as it did during the Han Dynasty; it vanishes into a desert approximately $200 \mathrm{~km}$ south of the main stem of the Tarim River. The Kuche and Dina Rivers (which once belonged to the Weigan River system) flow from the Tianshan Mountains in the north and also lost links to the Weigan River and then to the Tarim River during the late Qing Dynasty (Fig. 4 c); subsequently, the whole Weigan River system lost links to the Tarim River in the late 1950s as a result of ever increasing water consumption in its upstream reaches (Fig. 4 d). The Kashgar River in the west has had almost no surface runoff to the main stem of the Tarim River since the 1950s, when a reservoir was constructed on the River and blocked the river flow. The Yarkand River once had an annual runoff of approximately $1-1.5$ billion $\mathrm{m}^{3}$ moving downstream to the Tarim River, but the volume has gradually declined to almost zero since the 1980s due to the over-consumption of water resources in its upstream reaches (Hu et al., 2005) (Fig. 4 c, d). The lower Hotan River also became an ephemeral river with only low runoff to the Tarim River during main flood seasons.

Despite the case of the Keriya River evolution, which was regarded as more of the result of natural environmental change (including the tectonic movement of the Kunlun Mountains and climate change) (e.g., Yang, 1990; Yang, 2001), the evolution of other tributaries mainly took place in the last century, with human activities serving as the leading driver. The Tarim River network system has been disaggregated from a historically complex quasi-centripetal system into several isolated small river systems, and the complexity of the river network decreased.

Though it is not a new fact that the drainage composition of the Tarim River has changed from the previous 9 tributaries to the current 4 tributaries, the sketch maps of the river network during different periods still show us valuable information about what the river network (composition) was like historically, although the specific river route (channel path) and length may not be exactly precise during the West Han (1800 years ago) and middle Qing
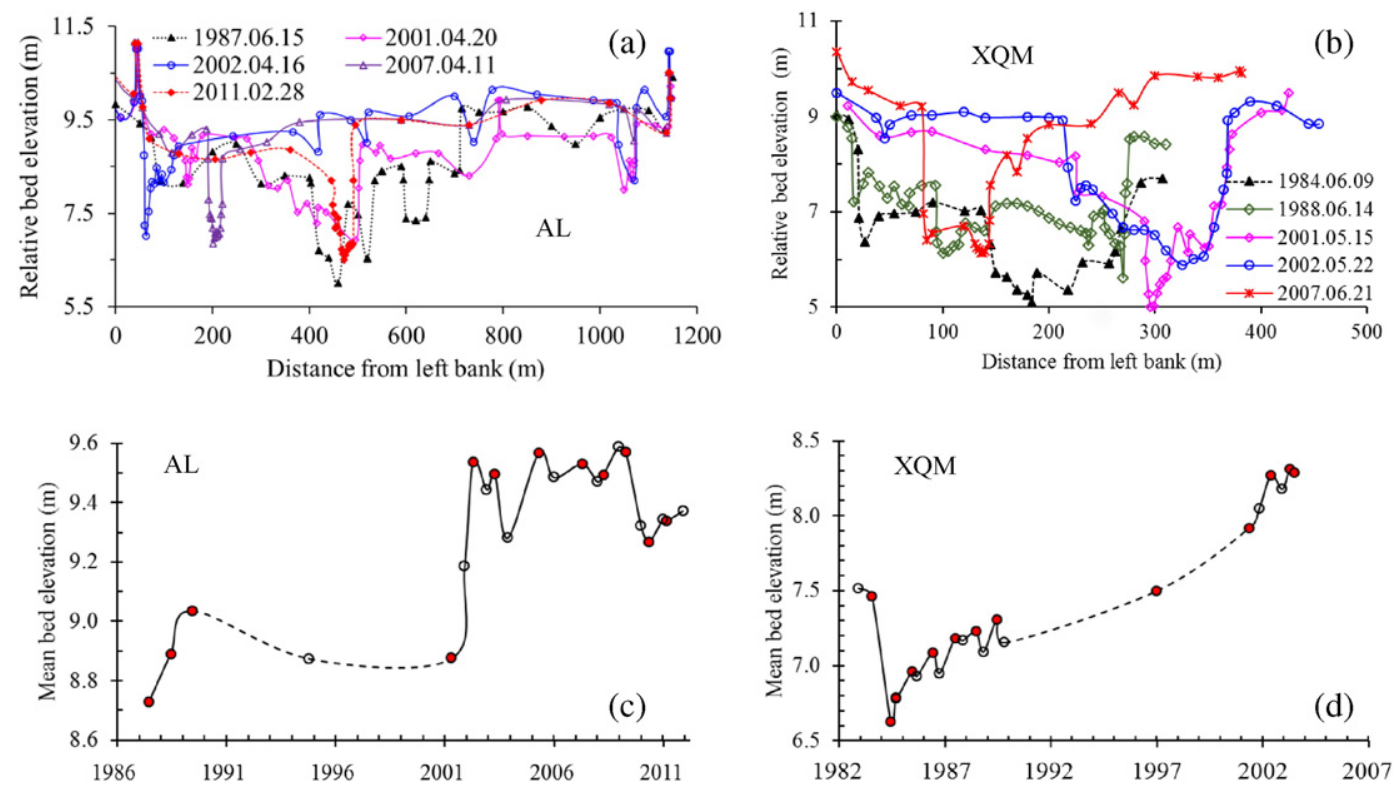

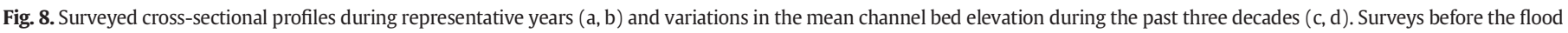

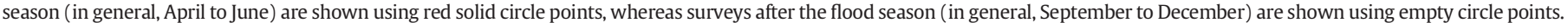


(mid-18th century) dynasties. Importantly, this gives us a somewhat general while deep view of the evolution of the river network, that is, when and what major changes occurred to the river network composition and the potential links between the river network evolution and human activities in the basin.

4.2. Change in hydraulic features and fluvial morphology during recent decades

\subsubsection{Hydrologic regimes and sediment transport}

Due to the ever-increasing water diversion from the Tarim River for agricultural and urban use, annual runoff followed a fluctuating decrease, as shown in Fig. 2. Meanwhile, the annual dates of low flow events (analyzed by the mean daily flow discharge, $\mathrm{Q}<50 \mathrm{~m}^{3} / \mathrm{s}$ at AL and $\mathrm{Q}<40 \mathrm{~m}^{3} / \mathrm{s}$ at XQM) exhibited an obvious increasing trend, and the date of moderate-high flow events (with a mean daily flow discharge of $\mathrm{Q}>500 \mathrm{~m}^{3} / \mathrm{s}$ at $\mathrm{AL}$ and $\mathrm{Q}>400 \mathrm{~m}^{3} / \mathrm{s}$ at XQM) exhibited a very gentle decreasing trend (Fig. $5 \mathrm{a}, \mathrm{b}$ ). The ratio of runoff at the QL station to that at the AL station from the late 1950s to 2011 also indicated a clear downward trend, although the rate of decrease has slowed down since the 1980s (Fig. 5 c). Corresponding to the changed flow regime, the annual sediment load (Fig. 6) also exhibited a clear fluctuating and decreasing trend in recent decades.

As a common feature of dryland rivers, runoff and sediment load along the river decline spatially from upstream to downstream (Fig. 2 a). The problem is, over just a few decades, the ending point of the

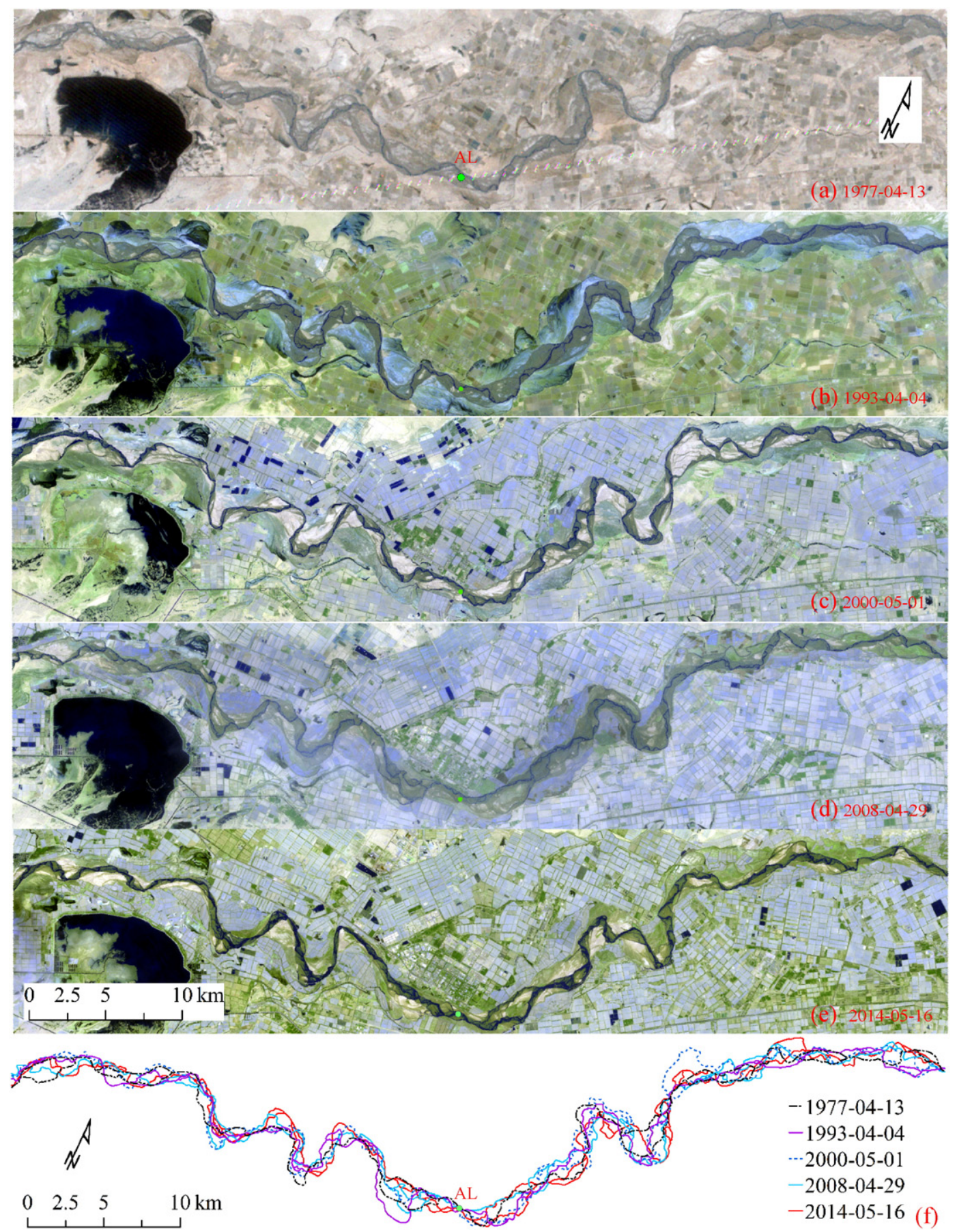

Fig. 9. Planform variation of channel routes of the braided reach (RA) near AL during the past four decades. 
Tarim River has moved upstream from a previous location at Lop Nor, then to Taitema Lake and finally to Daxihaizi Reservoir (Fig. 1), which was built in the 1960s. In recent years, the reach of the main stem Tarim River upstream from the Daxihaizi Reservoir to YBZ (and even to XQM) sometimes dried up in the non-flood season as a result of the over-consumption of water resources in the tributary regions. The mean value of the annual sediment load along the QL reach was very low (0.2 million tons), meaning that almost no sediment was transported farther downstream from QL; in other words, almost the total sediment load from AL (approximately 22 million tons) was deposited along the reaches between the AL-QL or was diverted to farmland along both banks during the flow diversion.

\subsubsection{Channel morphology}

The channel bed and banks are mainly composed of coarse silt and very fine sand (Fig. 7 a). The sediment composition is quite homogeneous, with a sorting index (here, we use $\varphi=D_{80} / D_{20}$ ) typically ranging from 1.4 to 1.6 (Fig. $7 \mathrm{~b}$ ) and lacking in clay content. This makes the channel banks very weak and prone to channel shifting and bank failure.

Two typical channel patterns, braided and meandering, developed along the current main stem of the Tarim River. The braided channel pattern is mainly distributed from XJK (the confluence site of the three upstream tributaries) to XQM with a channel length of approximately $250 \mathrm{~km}$ (Fig. 1, Fig. 2 a). Downstream from XQM, the channel width gradually reduces and the channel pattern changes from braided
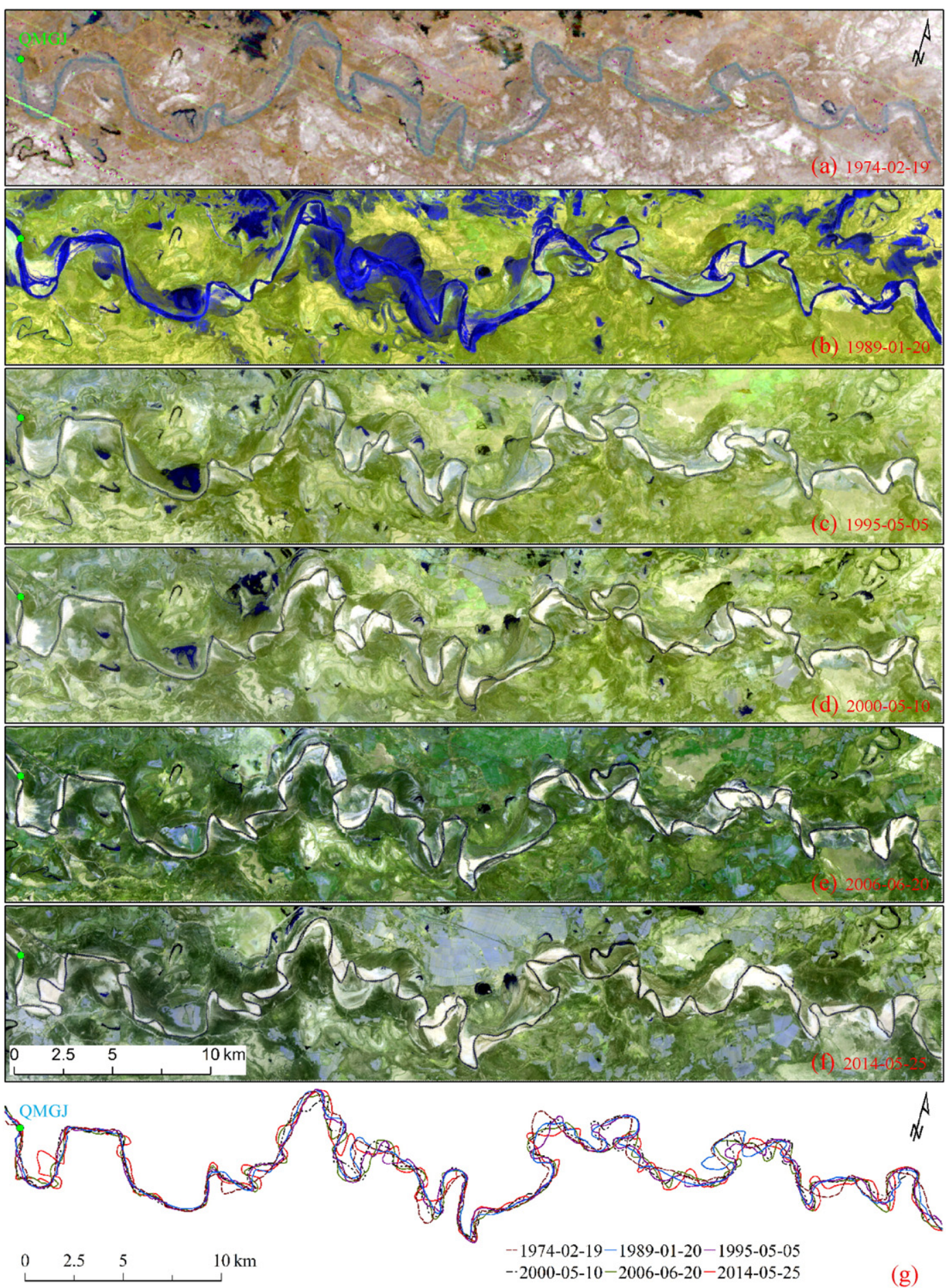

Fig. 10. Planform variation of the channel route of the meandering reach (RB) downstream from QMGJ during the past four decades. 
to meandering pattern. The typical meandering channel mainly distributes downstream from QMGJ, a site approximately $25 \mathrm{~km}$ downstream from XQM (Fig. 1, Fig. 2 a).

The braided channel in the upper reaches of the Tarim River was quite unstable due to very low riverbank strength, highly varied flow discharge and a concentrated sediment load. Surveyed cross sectional profiles at AL and XQM in the last three decades have shown that the channel had strong lateral mobility in planform and that the position of the channel thalweg has been constantly changing (Fig. 8 a, b). Both the mean channel bed elevation at $\mathrm{AL}$ and $\mathrm{XQM}$ showed a fluctuating and silting trend, especially at XQM (Fig. $8 \mathrm{c}, \mathrm{d}$ ), and the aggradation majorly occurred after the flood season, whereas scouring (incision) mainly occurred in the main flood season.

Two representative reaches, one braided reach near AL (Reach RA) and one meandering reach downstream from QMGJ (Reach RB), were chosen to examine the channel planform pattern variations during recent decades (the locations are shown in Fig. 1). Satellite images covering the representative braided and meandering reaches are shown in Figs. 9 and 10.

Consistent with the surveyed cross section profiles shown in Fig. 8, a strong braiding feature can be seen in Fig. 9 (a-e). The channel centerlines during different periods followed strong lateral variations (shifting) (Fig. 9 f). Both the calculated mean channel width and braiding intensity of the reach RA followed an obvious decreasing trend (Fig. $11 \mathrm{a}, \mathrm{b}$ ). The channel embankments and gradual occupation (reclamation) of previous river flood plains and convex banks to farmlands, as clearly shown in images in Fig. 9 (a-e), should be the major reason for channel narrowing.

The meandering reaches of the Tarim River are also quite unstable, with continuous meander development (even cutoffs), as shown by the reach RB downstream of QMGJ in Fig. 10. The calculated mean channel width and channel sinuosity index of the meandering reach $R B$ in recent decades showed a gentle decreasing and increasing trend, respectively (Fig. $11 \mathrm{a}, \mathrm{b}$ ).

A comparison of the planform features of the current and old (abandoned) channels was also conducted. The results were analyzed based on tree ring samples from YBZ and QL and indicated that trees near the current channels are four to six decades old, whereas trees near the old channels are approximately 150 years old (Table 3 ). It is reasonable to conclude that the current river channel has generally maintained its route for at least six decades, whereas the old channels were formed at least 150 years or more ago, and they were abandoned at least six decades ago, as there was no report on natural avulsion along the main stem of the Tarim River in the last six decades. This indicates that the old (abandoned) channels have not undergone intensified human interventions, which started in the late 1950s.

The sediment composition and planform features of the current and old (abandoned) channels were quite different. The sediment composition of the current channel was much coarser than the old channels and was quite similar to the size distribution of aeolian sand in the nearby Taklamakan Desert (Fig. 7). The sinuosity index also differed quite clearly between the current and old channels. The current river channel in the upper (e.g., channel I in Fig. 12 a) and middle (e.g., channel VI in Fig. 12 b) reaches of the main stem of the Tarim River was generally less meandering than the adjacent old channels, which were abandoned decades or centuries ago (e.g., channels II-V in Fig. 12 a and VII-VIII in Fig. 12 b) but were still quite visible in satellite images. The meandering intensities (mean sinuosity index over a certain channel reach) of current meandering channels were lower than the old channels (Fig. 12 c). This may imply that human activity has changed the original features of the Tarim River and has restrained, to some extent, the evolution of channel patterns (meander development and channel avulsion).

\section{Discussion}

Consistent with results from other studies (e.g., Fan, 1979; Xia and Fan, 1987; Yang, 1990; Yang, 2001; Fan et al., 2006; Hao et al., 2009; Duan et al., 2009; Fu et al., 2010; Dong et al., 2013; Xu et al., 2013), climate change has been proposed as the main contributor to regional environmental evolution on a geological time scale (e.g., Sinitsin, 1956; Yang, 1990; Yang, 2001) or to runoff variation in the headwaters of mountainous regions (e.g., Tao et al., 2011; Ling et al., 2014); however, human activity (land reclamation, agriculture, flow regulation and water diversion) should be considered as the primary reason for changes in the hydrologic regime and the decline in the natural environments of the Tarim River over recent centuries, especially in recent decades, which inevitably had significant impacts on the evolution of river networks and channel morphology. This is similar to cases in other arid regions, such as the Murray River in southeast Australia (Maheshwari et al., 1995) and rivers in the arid southwest of the United States of America (Graf, 1988).

\subsection{Major controls of fluvial processes in the Tarim River}

Results in this study indicate that the human intervention (evaluated with inhabitants and farmland area) in the Tarim basin was relatively trivial before the early 20 th century because the inhabitant population and farmland area was small then (c.f., Table 2). The situation changed since 20th century, especially after the 1950s during which time human inhabitants and land reclamation both increased obviously, which is consistent with the evolution of river network system (Fig. 4). Hence, it is reasonable to deduce that human factors has significant influences on fluvial morphology and river system since 20th century, in particular after 1950s. Among different human factors, flow regulation and agricultural water consumption should be the major controls which played a key role on fluvial processes and river network evolution since the factors directly altered the natural hydrologic regime.

Analysis on spatial variation of channel sediment size distribution (Fig. 7), temporal variation of mean channel width, and braiding intensity/sinuosity index (Fig. 11) show that human intervention in recent decades has changed the original features of the Tarim River and has restrained, to some extent, the evolution of channel patterns (meander development and channel avulsion). One of the main reasons may lie in the increased annual occurrence of low flow events with a decreased occurrence of moderate-high flow events in recent decades (Fig. 5 a, b)
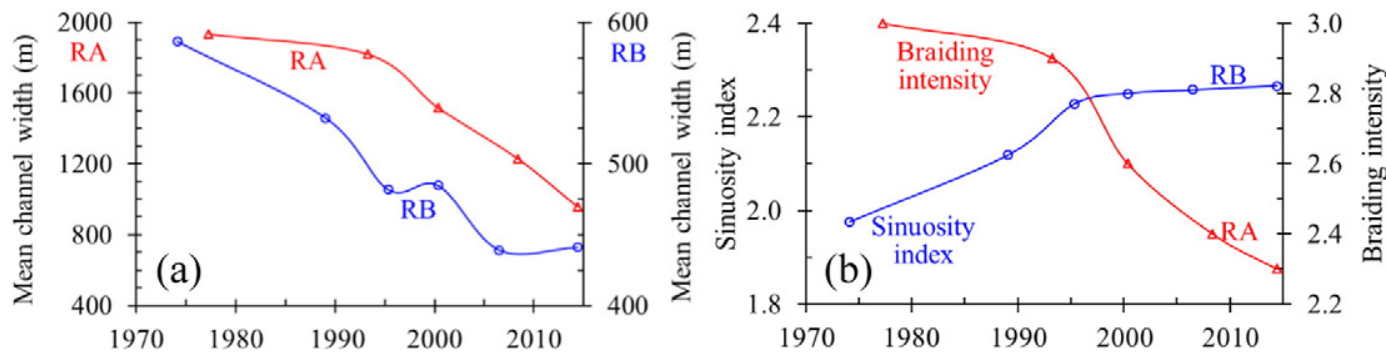

Fig. 11. Variations in the mean channel width (a) and braiding intensity/sinuosity index (b) of the analyzed reach of RA and RB during recent decades. 
Table 3

Age of sampled trees near the current and old channels along the main stem of the Tarim River.

\begin{tabular}{llllllll}
\hline & \multicolumn{2}{l}{ Current channel } & & & \multicolumn{2}{l}{ Old channel } \\
\cline { 2 - 4 } \cline { 7 - 8 } $\begin{array}{l}\text { Sampling } \\
\text { site }\end{array}$ & $\begin{array}{l}\text { Age } \\
\text { range }\end{array}$ & $\begin{array}{l}\text { Mean } \\
\text { age }\end{array}$ & $\begin{array}{l}\text { No. of } \\
\text { samples }\end{array}$ & & $\begin{array}{l}\text { Age } \\
\text { range }\end{array}$ & $\begin{array}{l}\text { Mean } \\
\text { age }\end{array}$ & $\begin{array}{l}\text { No. of } \\
\text { samples }\end{array}$ \\
\hline YBZ & $29-55$ & 40 & 24 & & $149-154$ & 152 & 7 \\
QL & $33-103$ & 66 & 9 & & & \\
\hline
\end{tabular}

since the flow regime changed due to ever-increasing water consumption and flow diversion.

Three major controls are often considered when analyzing the causes of fluvial morphology evolution: the flow regime, sediment regime and vegetation (both riparian and catchment-wide). The three controls in the Tarim Basin have been undergoing changes (significant or gentle); in particular, these changes have occurred during the last five decades because of ever-increasing human interventions, which correspondingly influence fluvial processes (e.g., aggradation or incision, variation of channel width, braiding intensity and sinuosity index). However, the change in the fluvial morphology of the Tarim River has mainly been caused by changes in the hydrological regime, more specifically due to the decrease in runoff, increase in the number of low flow events, decrease in moderate-high flow events and induced change in the sediment regime (decrease in sediment transport capacity) along the river, which influenced sediment transport and channel morphology (e.g., channel width, braiding intensity and sinuosity index). It should be pointed out that the change of vegetation in basin (not riparian vegetation) actually has little effect on the flow hydrology, sediment erosion and fluvial processes because it has little effect on local surface runoff, sediment erosion and transport due to the negligible local precipitation and high land seepage capacity in this very arid environment. The dynamic of decreases in vegetation cover in the basin not causing sediment load increases in the Tarim River may support this conclusion because a decrease in vegetation cover is in general associated with increased sediment production and vice versa (Walling, 1999). This is different and somehow special compared to studies in other regions, which have shown how the change in vegetation played an important role in the sediment regime and fluvial morphology (e.g., Graf, 1978, 1979, 1988; Brooks and Brierley, 1997; Liébault et al., 2005; Lazarus and Constantine, 2013).

Nevertheless, the change in vegetation cover in the Tarim Basin may have impacts on the aeolian-fluvial effects in the Tarim River because the river is adjacent to the Taklamakan Desert, which is the world's second largest shifting sand desert with approximately $85 \%$ of its area composed of shifting sand dunes.
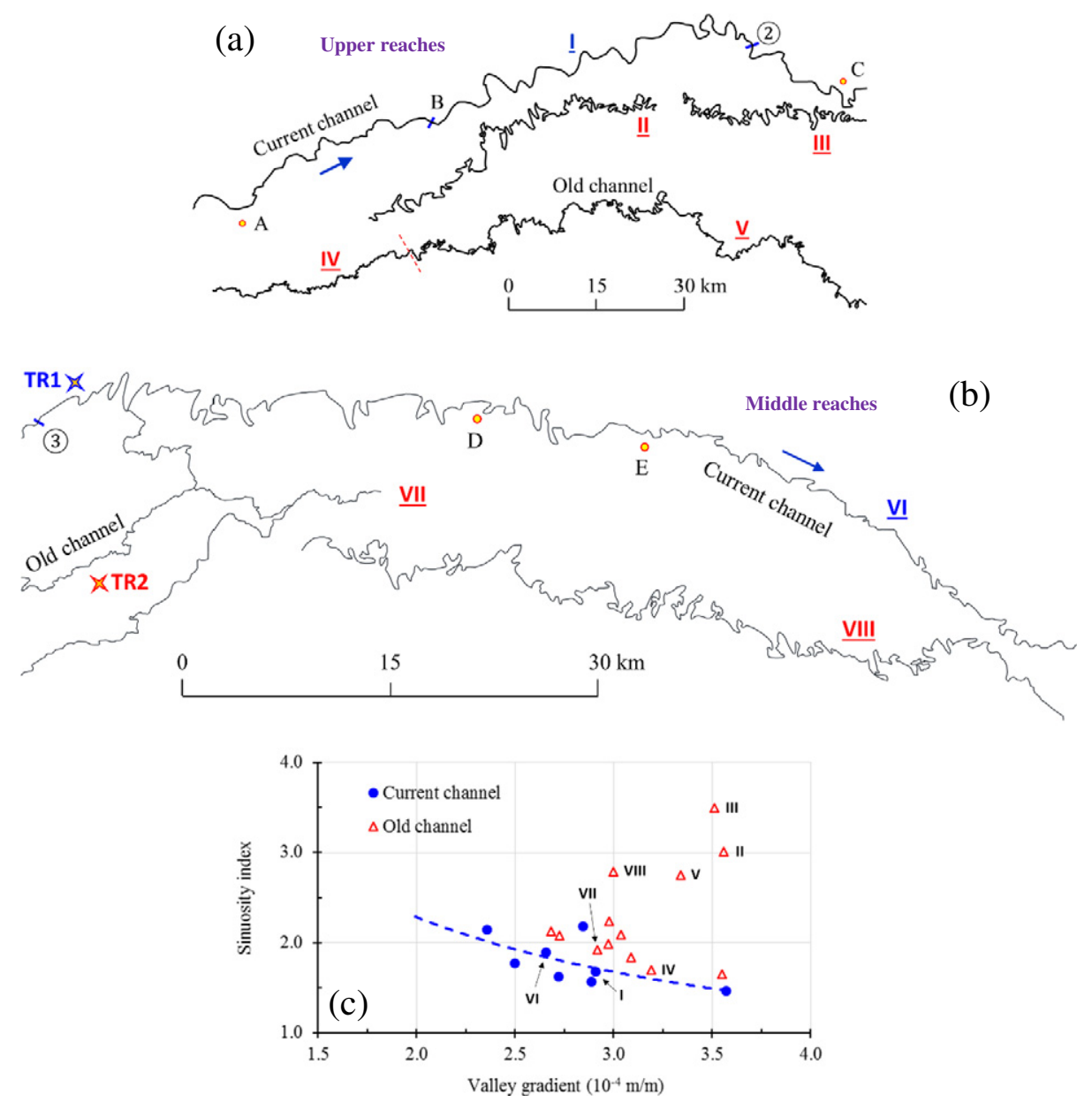

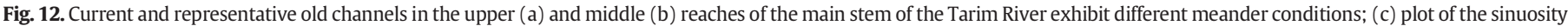

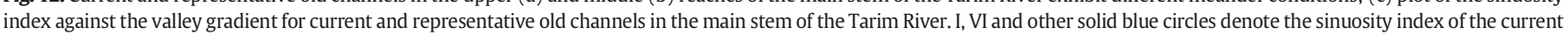

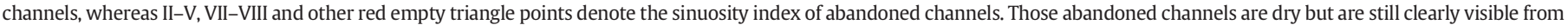

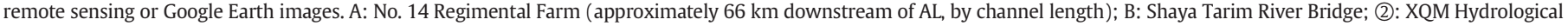

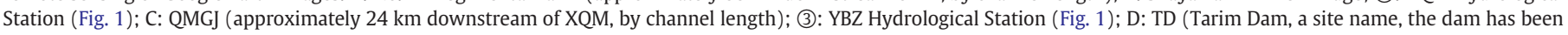
removed); E: Yinjigela (approximately $93 \mathrm{~km}$ upstream of WSM, by channel length). 


\subsection{Potential influence of aeolian effects}

Though further studies are needed to understand how the aeolian effects interact with the fluvial processes of the Tarim River and to determine how human activities influence the aeolian-fluvial interactions, a preliminary comparison of the channel bed sediment size distribution may provide some hints. In general, the size of the sediment from the current channel is obviously coarser than from the old (abandoned) channels (Fig. 7 b, sample from YBZ, 'BK_Old channel near YBZ'). The size of the sediment in the channel of the upper reaches $(A L)$ is quite similar to aeolian sediment from the nearby desert and generally becomes finer from upstream to the middle reaches (XQM, YBZ, and WSM), indicating that the morphology of the upper and middle reaches of the current channel is still shaped by fluvial processes and at the same time subordinately influenced by aeolian effects. However, the size of sediment downstream from QL is abnormally coarser than sediment samples in upstream reaches and even coarser than aeolian samples, which may reflect stronger aeolian effects in the downstream reach; because less runoff occurred in recent decades in the downstream reach, fluvial processes are not as effective in this reach compared with upper and middle reaches; rather, the channel morphology is more likely influenced by aeolian effects. Therefore, the size composition of sediment from this channel is coarser due to wind sorting processes.

\subsection{Potential future evolution of fluvial morphology}

The change in the flow regime caused changes in the sediment regime and influenced the spatial distribution of sediment deposition. Because sediment transport mostly occurred during moderate-high flow events (for AL reach, $\mathrm{Q}>500 \mathrm{~m}^{3} / \mathrm{s}$, XQM reach, $\mathrm{Q}>400 \mathrm{~m}^{3} / \mathrm{s}$ ), the decrease in the occurrence of moderate-high flow events will induce decreased sediment carrying capacity. Consequently, sediment deposition is prone to occur in the upper reaches of the main stem of the Tarim River, as the obvious aggradation at XQM has shown (Fig. 8 b, d). Correspondingly, the aggradation in the middle reaches of the river may be attenuated and even reach a dynamic equilibrium. Over a longer timeframe, the fluvial processes of the river (spatial distribution of sediment load and aggradation, channel shifting and meander development) will be increasingly modified, which may even influence the evolution of the channel pattern, given the ever-increasing human interventions (water regulation and diversion and land reclamation) on the flow and sediment regime.

\section{Conclusions}

Widespread, ever-increasingly intense human activities in the Tarim River Basin over recent centuries (particularly since the late 1950s) have exerted a strong impact on the flow regime and sediment dynamics, which have influenced the river network evolution and caused major changes in river morphology (especially planform). With the obvious decrease in runoff into the Tarim River during the last five decades, there has been increased annual occurrence of low flow events and a fluctuating and gentle decrease in moderate-high flow events and sediment loads. Consequently, the mean channel width of the current channel gradually decreased, the braiding intensity of the braided reach also descended, while the sinuosity index of the meandering reach exhibited a gentle increase. Despite this, the sinuosity index of the current river channel was distinctly lower than those of old channels that were abandoned decades or centuries ago. The historic (quasi-) centripetal river network system with nine tributaries has gradually disaggregated into several isolated river systems, mainly since the 20th century, in response to ever-increasing human impacts. Human activity has changed the natural fluvial processes and morphology of the Tarim River and has reduced the complexity and diversity of the river network system.

\section{Acknowledgements}

The first author was supported by the Alexander von Humboldt Foundation. This study was also supported by the National Natural Science Foundation of China (NSFC, Nos. 41571009; 41330751; 91547112; 41202134) and the German-Sino bilateral collaboration research project SuMaRiO (Sustainable Management of River Oases along the Tarim River/China, 2012-2016). The authors are grateful to Ruide Yu, Ru Feng and Zhijie Ta (Xinjiang Institute of Ecology and Geography, Chinese Academy of Sciences) for their assistance during the field investigations and Zhentao Cong (Tsinghua University) for data support during this study. We would also like to thank two anonymous referees for their very constructive comments and suggestions.

\section{References}

Achite, M., Ouillon, S., 2007. Suspended sediment transport in a semiarid watershed Wadi Abd, Algeria (1973-1995). J. Hydrol. 343, 187-202.

Alexandrov, Y., Laronnea, J.B., Reid, I., 2003. Suspended sediment concentration and its variation with water discharge in a dryland ephemeral channel, northern Negev, Israel. J. Arid Environ. 53 (1), 73-84.

Brooks, A.P., Brierley, G.J., 1997. Geomorphic responses of the lower Bega River to catchment disturbance, 1851-1926. Geomorphology 18, 291-304.

Chen, Y.N., Chen, Y.P., Xu, C.C., Ye, Z.X., Li, Z.Q., Zhu, C.G., Ma, X.D., 2010. Effects of ecological water conveyance on groundwater dynamics and riparian vegetation in the lower reaches of Tarim River, China. Hydrol. Process. 24, 170-177.

Chen, Y.N., Xu, C.C., Hao, X.M., Li, W.H., Chen, Y.P., Zhu, C.G., Ye, Z.X., 2009. Fifty-year climate change and its effect on annual runoff in the Tarim River Basin, China. Quat. Int. 208, 53-61.

Cheng, W.L., He, P., Guan, C.H., Liu, Y.H., Li, W.D., 2012. Historical development of Populus euphratica in the upper stream of Tarim River and its causes. J. Anhui Agr. Sci. 40 (29), 14292-14294 (in Chinese).

Chin, A., Gregory, K.J., 2001. Urbanization and adjustment of ephemeral stream channels Ann. Assoc. Am. Geogr. 91, 595-608.

Coleman, D., MacRae, C., Stein, E.D., 2005. Effect of increases in peak flows and imperviousness on the morphology of southern California streams. Technical Report 450. Southern California Coastal Water Research Project, Costa Mesa, CA (70 p).

Dong, W., Cui, B.S., Liu, Z.H., Zhang, K.J., 2013. Relative effects of human activities and climate change on the river runoff in an arid basin in northwest China. Hydrol. Process. 28 (18). http://dx.doi.org/10.1002/hyp.9982.

Duan, J.J., Wang, Y.G., Wang, X.F., Mao, W.Y., Zhang, X.W., Wang, J., Gao, Q.Z., Shen, Y.P., Wang, S.D., 2009. Impact of climate change and human activities on the water resources and ecological environments in the Tarim River Basin in 1957-2006. J. Glaciol. Geocryol. 31 (5), 781-791 (in Chinese).

Egozi, R., Ashmore, P., 2008. Defining and measuring braiding intensity. Earth Surf. Process. Landf. 33 (14), 2121-2138. http://dx.doi.org/10.1002/esp.1658.

Fan, Z.L., 1979. Preliminary study on drainage network evolution of Tarim River in history Arid Land Geogr. 2, 20-36 (in Chinese).

Fan, Z.L., Alishir, K., Xu, H.L., Zhang, Q.Q., Abdumijiti, 2009. Changes of Tarim River and evolution of Lop Nor. Quaternary Sci. 29 (2), 232-243 (in Chinese).

Fan, Z.L., Chen, Y.N., Wang, Y.J., 2006. Study on the Tarim River and its water course evolution in Xinjiang: recorded in the "Records of Rivers". Arid Zone Res. 23 (1), 8-15 (in Chinese).

Feng, Q., Cheng, G.D., 1998. Current situation, problem and rational utilization of water resources in arid north-western China. J. Arid Environ. 40, 373-382.

Feng, Q., Liu, W., Si, J.H., Su, Y.H., Zhang, Y.W., Cang, Z.Q., Xi, H.Y., 2005. Environmental effects of water resource development and use in the Tarim River basin of northwestern China. Environ. Geol. 48 (2), 202-210.

Fu, L.X., Chen, Y.N., Li, W.H., He, B., Xu, C.C., 2010. Relation between climate change and runoff volume in the head waters of the Tarim River during the last 50 years. J. Desert Res. 30 (1), 204-209.

Graf, W.L., 1978. Fluvial adjustments to the spread of tamarisk in the Colorado Plateau region. Geol. Soc. Am. Bull. 89, 1491-1501.

Graf, W.L., 1979. Fluvial adjustments to the spread of tamarisk in the Colorado Plateau region: reply. Geol. Soc. Am. Bull. 90, 1183-1184.

Graf, W.L, 1988. Fluvial Processes in Dryland Rivers. Springer-Verlag, Berlin, Germany.

Gregory, K.J., 2006. The human role in changing river channels. Geomorphology 79, $172-191$.

Han, Q., 1980. On the deterioration of water quality and its control after large-scale reclamation in the Tarim Basin. Acta Geograph. Sin. 35 (3), 219-231 (in Chinese).

Hao, X.M., Chen, Y.N., Li, W.H., 2009. Impact of anthropogenic activities on the hydrologic characters of the mainstream of the Tarim River in Xinjiang during the past 50 years. Environ. Geol. 57, 435-445.

Hawley, R.J., Bledsoe, B.P., 2011. How do flow peaks and durations change in suburbanizing semi-arid watersheds? A southern California case study. J. Hydrol. 405 (1-2), 69-82.

Hawley, R.J., Bledsoe, B.P., 2013. Channel enlargement in semiarid suburbanizing watersheds: A southern California case study. J. Hydrol. 496, 17-30.

Hedin, S., 1898. The map of Tarim basin and northern Tibet. Through Asia Vol. II. Methuen \& Co., London. 
Hedin, S., 1904. Scientific Results of a Journey in Central Asia 1899-1902. Vol. 1, the Tarim River. Lithographic Institute of the General Staff of the Swedish Army, Stockholm.

Hoffman, T., Thorndycraft, V.R., Brown, A.G., Coulthard, T.J., Damnati, B., Kale, V.S. Middelkoop, H., Notebaert, B., Walling, D.E., 2010. Human impact on fluvial regimes and sediment flux during the Holocene: review and future research agenda. Glob. Planet. Chang. 72, 87-98.

Howard, A.D., Keetch, M.E., Vincent, C.L., 1970. Topological and geometrical properties of braided streams. Water Resour. Res. 6, 1674-1688.

Hu, C.H., Wang, Y.G., Guo, Q.C., Hu, J.H., 2005. Fluvial Processes and Regulation of the Main Stem Tarim River. Science Press, Beijing (in Chinese).

Jacobson, P.J., Jacobson, K.M., Seeley, M.K., 1995. Ephemeral Rivers and Their Catchments: Sustaining People and Development in Western Namibia. Desert Research Foundation of Namibia, Windhoek.

Knighton, A.D., Nanson, G.C., 1994. Flow transmission along an arid zone anastomosing river, Cooper Creek, Australia. Hydrol. Process. 8, 137-154.

Knighton, A.D., Nanson, G.C., 1997. Distinctiveness, diversity and uniqueness in arid zone river systems. In: Thomas, D.S.G. (Ed.), Arid Zone Geomorphology: Processes, Form and Change in Drylands, second ed. John Wiley and Sons, Chichester, England.

Knighton, A.D., Nanson, G.C., 2001. An event-based approach to the hydrology of arid zone rivers in the Channel Country of Australia. J. Hydrol. 254, 102-123.

Laronne, J.B., Reid, I., 1993. Very high rates of bedload sediment transport by ephemeral desert rivers. Nature 366, 148-150.

Lazarus, E.D., Constantine, J.A., 2013. Generic theory for channel sinuosity. PNAS 110 (21), $8447-8452$

Leopold, L.B., Miller, J.P., 1956. Ephemeral streams - hydraulic factors and their relation to the drainage net. United States Geological Survey Professional Paper. 282-A.

Leopold, L.B., Wolman, M.G., Miller, J.P., 1964. Fluvial Processes in Geomorphology. W. H. Freeman \& Company, San Francisco.

Liébault, F., Gomez, B., Page, M., Marden, M., Peacock, D., Richard, D., Trotter, C.M., 2005. Land-use change, sediment production and channel response in upland regions. River Res. Appl. 21, 739-756.

Ling, H.B., Xu, H.L., Fu, J.Y., 2014. Changes in intra-annual runoff and its response to climate change and human activities in the headstream areas of the Tarim River Basin, China. Quat. Int. 336, 158-170.

Lu, X.D., An, J.W., Ren, B.J., 1980. Aerial Investigation of Populus euphratica forest in Tarim Basin. Xinjiang Forest. 1980 (6), 1-12 (in Chinese)

Maheshwari, B.L., Walker, K.F., McMahon, T.A., 1995. Effects of regulation on the flow regime of the River Murray, Australia. Regul. River. 10, 15-38.

Mansur, S., Lutpulla, I., 2011. Land Use Change and its Eco-effects in Southern Xinjiang. China, Scientia Geographica Sinica 31 (4), 440-446 (in Chinese).

Mansur, S., Nurkamil, Y., 2010. Oasis land use change and its hydrological response to Tarim River Basin. Geogr. Res. 29 (12), 2251-2260 (in Chinese).

McDonald, A.K., Sheng, Z., Hart, C.R., Wilcox, B.P., 2013. Studies of a regulated dryland river: surface-groundwater interactions. Hydrol. Process. 27, 1819-1828.

Ortega, J.A., Razola, L., Garzón, G., 2014. Recent human impacts and change in dynamics and morphology of ephemeral rivers. Nat. Hazards Earth Syst. Sci. 14, 713-730.

Powell, D.M., Laronne, J.B., Reid, I., Barzilai, R., 2012. The bed morphology of upland singlethread channels in semi-arid environments: evidence of repeating bedforms and their wider implications for gravel-bed rivers. Earth Surf. Process. Landf. 37, 741-753.

Reid, I., Frostick, L.E., 2011. Channel form, flows and sediments of endogenous ephemera rivers in deserts. In: Thomas, D.S.G. (Ed.), Arid Zone Geomorphology: Process, Form and Change in Drylands, third ed. John Wiley \& Sons, Ltd, Chichester, UK http://dx. doi.org/10.1002/9780470710777.ch13.
Rhoads, B.L., Lewis, Q.W., Andresen, W., 2015. Historical changes in channel network extent and channel planform in an intensively managed landscape: natural versus human-induced effects. Geomorphology http://dx.doi.org/10.1016/j.geomorph. 2015.04.021.

Schick, A.P., 1995. Fluvial processes on an urbanizing alluvial fan: Eilat, Israel. In: Costa, J.E., Miller, A.J., Potter, K.W., Wilcock, P.R. (Eds.), Natural and Anthropogenic Influences in Fluvial Geomorphology. American Geophysical Union, Washington, DC, pp. 209-218.

Sinitsin, B.M., 1956. Geotectonic factor of climatic vicissitudes in Central Asia (Translated). Translated Rep. of Geogra. 4, pp. 260-267 (in Chinese).

Surian, N., Rinaldi, M., 2003. Morphological response to river engineering and management in alluvial channels in Italy. Geomorphology 50, 307-326.

Tao, H., Gemmer, M., Bai, Y.G., Su, B.D., Mao, W.Y., 2011. Trends of streamflow in the Tarim River Basin during the past 50 years: human impact or climate change? J. Hydrol. 400 (1-2), 1-9.

Thomas, D.S.G. (Ed.), 2011. Front Matter. In: Arid Zone Geomorphology: Process, Form and Change in Drylands, third ed. John Wiley \& Sons, Ltd, Chichester, UK http://dx. doi.org/10.1002/9780470710777.fmatter.

Thoms, M.C., Sheldon, F., 2000. Water resource development and hydrological change in a large dryland river: the Barwon-Darling River, Australia. J. Hydrol. 228 (1-2), 10-21.

Thornes, J.B., 1994. Channel processes, evolution and history. In: Abrahams, A.D., Parsons, A.J. (Eds.), Geomorphology of Desert Environments. Chapman \& Hall, London, pp. 288-317.

Tooth, S., 2000b. Downstream changes in dryland river channels: the Northern Plains of arid central Australia. Geomorphology 34 (1-2), 33-54.

Tooth, S., 2000a. Process, form and change in dryland rivers: a review of recent research. Earth-Sci. Rev. 51, 67-107.

Tooth, S., Nanson, G.C., 1999. Anabranching rivers on the Northern Plains of arid central Australia. Geomorphology 29, 211-233.

Tooth, S., Nanson, G.C., 2004. Forms and processes of two highly contrasting rivers in arid central Australia, and the implications for channel-pattern discrimination and prediction. Geol. Soc. Am. Bull. 116 (7/8), 802-816. http://dx.doi.org/10.1130/B25308.1.

Tooth, S., Nanson, G.C., 2011. Distinctiveness and diversity of arid zone river systems. In: Thomas, D.S.G. (Ed.), Arid Zone Geomorphology: Process, Form and Change in Drylands, third ed. John Wiley \& Sons, Ltd, Chichester, UK http://dx.doi.org/10.1002/ 9780470710777.ch12.

Walling, D.E., 1999. Linking land use, erosion and sediment yields in river basins. Hydrobiologia 410, 223-240.

Wang, S.C., 1987. Textual research on the "South River" of Tarim Basin recorded by "Records of Rivers (Shui Jing Zhu)". Geogr. Res. 6 (4), 36-44 (in Chinese)

Wohl, E., 2006. Human impacts to mountain streams. Geomorphology 79, 217-248.

Xia, X.C., Fan, Z.L., 1987. On environment change and evolution in the Tarim Basin. Lop Nor Expedition Team of the Chinese Academy of Sciences. Scientific investigation and Research on Lop Nor. Science Press, Beijing, pp. 106-118 (in Chinese).

Xu, C.C., Chen, Y.N., Chen, Y.P., Zhao, R.F., Ding, H., 2013. Responses of surface runoff to climate change and human activities in the Arid region of central Asia: a case study in the Tarim River Basin, China. Environ. Manag. 51, 926-938.

Yang, X.P., 2001. The relationship between oases evolution and natural as well as human factors - evidences from the low reaches of the Keriya River, Southern Xinjiang, China. Earth Sci. Front. 8 (1), 83-89 (China U. Geosci. Beijing). (in Chinese).

Yang, Y.C., 1990. Formation and evolution on Keriya River landforms. Arid Land Geogr. 13 (1), 37-45 (in Chinese). 